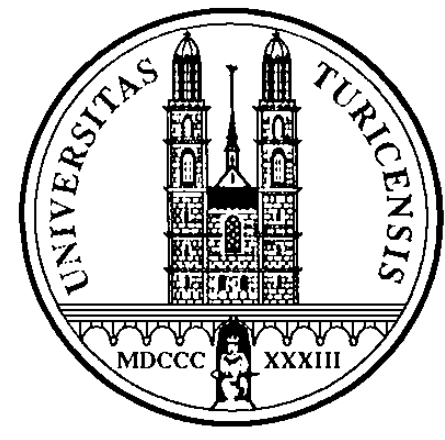

Institute for Empirical Research in Economics

University of Zurich

Working Paper Series

ISSN 1424-0459

Working Paper No. 48

The Rise and Fall of Festivals

Reflections on the Salzburg Festival

Bruno S. Frey

Juni 2000 


\title{
The Rise and Fall of Festivals
}

\section{Reflections on the Salzburg Festival}

\author{
Bruno S. Frey \\ (University of Zurich)
}

\begin{abstract}
The paper takes a closer look at cultural festivals such as musical or operatic festivals. From an economic viewpoint the paper shows that such festivals offer great artistic and economic opportunities, but that at the same time these opportunities are also easy to destroy. Empirical evidence from the Salzburg Festival show that government support can have negative effects on the innovative and economically success of festivals by introducing distorting incentives and imposing all sorts of restrictions. The paper draws policy suggestions on how the state can support art festivals.
\end{abstract}

Keywords: cultural economics, festivals, opera, government support, subsidies, regulation

JEL classification: Z11

\section{The Boom in Festivals}

Virtually every city, or at least region, in Europe has its own musical or operatic festival.

While the festivals at Bayreuth, Salzburg, Glyndebourne, or Spoleto may be older and more in the limelight than others, there are many thousands of festivals today ${ }^{1}$. Due to the problem

1 Only festivals devoted to serious music and operas are considered here. But even so, exactly what a music festival is, is ill-defined. There are, of course, many other types of "festivals", ranging from country music to jazz, theatre, circus or films. A classification is e.g. provided in Getz and Frisby (1988). Economists have tended to ignore art festivals as a general phenomenon; they have confined their attention to the local and regional multiplier effects of festivals (see, e.g., Vaughan 1980 for the Edinburgh Festival, Mitchell and Wall 1989 for the Stratford (Ontario) Festival, or O'Hagan 1992 for the Wexford Opera Festival), to the welfare theoretic implications of subsidization (e.g., O'Hagan and Duffy 1987; Pommerehne 1992), or to 
of how to define a music festival, no precise count exists; rough estimates range from one thousand (Pahlen 1978, Dümling 1992) to at least two thousand (Galeotti 1992). A detailed study by Rolfe (1992, p. 2) lists not less than 529 music festivals in Europe. Even in tiny Denmark, roughly 45 festivals take place every year. An enumeration for France counts 864 festivals, of which 40 percent are devoted to serious music (Maillard 1994, p. 65). Another source lists 600 festivals, of which 450 are devoted to serious art (L'Expansion 1994, p. 32). An official publication by the French Ministère de la Culture comes up with 245 festivals of serious music and opera for 1994.

Festivals became a significant part of the serious music and opera scene in the 1920s but the real boom took place within the last 20 years. When the official "Association Européenne des Festivals" was founded in 1952, there were 15 members as opposed to 58 now. Clearly, this Association is very restrictive and limited to the most prestigious festivals. In its special issue on musical events, L'Expansion (1994, p. 32) estimates, for example, that 6 out of 10 festivals in France have been founded in the 80s. Festivals usually take place in summer and are often very popular. Some festivals are permanently sold out and entrance tickets can then only be acquired by good connections, or on the black market. The most famous example is the Salzburg Festival, where ordinary visitors have to apply several times before they are able to purchase (a restricted number of) tickets.

The boom in music festivals stands in glaring contrast to the financial depression in which opera houses, orchestras and art museums find themselves. Many opera and concert houses are under such intense financial strain that they are forced to cut down their activities, dismiss artists, stage hands and other employees (if they are legally allowed to do so), or risk closing down completely. Unit labor costs of production in the live performing arts (or more generally in the service sector) steadily increase because the wage rates in this sector are rising at a rate similar to that in the economy as a whole, while labor productivity in the arts is more or less constant. This is the essence of the so-called Cost Disease. As a result, the live performing arts of opera, concert and theatre are faced with a secular threat of survival because of continually increasing cost 
relative to other consumption activities ${ }^{2}$. The relevance of the Cost Disease has been challenged for various reasons. In particular, if demand rises more quickly than that for other outputs (the income elasticity is larger than one), and the price elasticity of demand is larger than minus one, prices and revenues can possibly be raised sufficiently to keep pace with rising costs. In addition, labor productivity may to some extent be increased by switching to different art forms, for instance the use of chamber rather than symphony orchestras (Peacock 1984; Baumol and Baumol 1984), or by reducing the travel time of itinerant performers (Baumol 1993). The basic idea has, however, been generally accepted and provides a convincing explanation for why live performing arts suppliers are in perennial financial difficulties, and why many of them have not been able to survive.

But why is there such a boom in music festivals though they also produce live performing arts and should therefore run into the same financial problems as the established venues?

There are indeed major differences between festivals and established venues which serve to explain why the former are booming while the latter face perennial problems. Section II discusses factors on the demand side, and section III on the supply side. While festivals have a considerable potential to be artistically innovative and economically successful there is a constant danger that government intervention undermines this potential by introducing distorting incentives and imposing all sorts of restrictions. Section IV illustrates this tendency with the example of the Salzburg Festival. Section V suggests ways of how festivals can be kept lively and innovative.

\section{Demand}

The following features highlight the special conditions festivals experience with respect to the demand for their services:

1. High income effect. Consumers tend to spend an increasing share of rising income on visiting musical performances. Scattered empirical evidence exists, suggesting that econometrically estimated income elasticities of demand are greater than one. Throsby and Withers (1979, p. 113), for example, find an income elasticity for performing arts services

2 The analysis of the Cost Disease is due to Baumol and Bowen 1966, and is sometimes also called Baumol's law. Major contributions to the large subsequent literature on the topic are included in Towse (1997). 
of 1.55 for the United States 1949-73, and of 1.4 for Australia 1964-74 (full income). This means that the expenditures for the performing arts rise by 15.5 percent, and 14 percent, respectively, when the population's disposable income rises by 10 percent. Brosio and Santagata (1992, p.11) find for Italy that the share of expenditures for visiting the opera, ballet and concerts in total expenditures has risen from 1.1 percent in 1970 to 2.6 percent in 1988. The rise in attendance for performing art events is also documented in Baumol and Baumol (1984). Festivals thus find themselves in the comfortable position of being in a growing market. This does not, however, explain the growth in the number of festivals, as opposed to regular arts venues.

2. Attracting new groups of visitors. A large share of the population rarely, if ever, attends cultural events in opera and concert houses. Many people are overawed by the "temples of culture", feel insecure and unwelcome, and therefore do not even consider attending an opera performance. This applies, in particular, to population groups with little formal education, which are also short of cultural tradition (see Blau 1989, and DiMaggio and Useem 1989).

The situation clearly differs for special cultural events which are broadly advertised, and which are made attractive to new groups. This holds in particular for music festivals taking place in "public spaces", thus being more amenable to the great mass of the population, and less prohibitive than the established temples of culture (see e.g. Rolfe 1992, p. 82). Indeed, many festivals make a big effort to "go to the people" by e.g. playing in sport stadiums or popular meeting places (such as inner-city parks) ${ }^{3}$.

3. Focusing attention. A festival seeks to attract consumers by presenting some extraordinary cultural experience. They specialize on some particular artist (e.g. on Mozart), some period (e.g. Renaissance music), some topic (e.g. courtly music), some genre (e.g. mannerist music), or some type of presentation (e.g. original musical instruments). As a result, the visitors interested in such particular forms of art come together, often from far away locations. This development is supported by low and secularly falling travel costs.

Further contributions can be found in the special issue of the Journal of Cultural Economics (Vol. 20, No. 3,1996 ) devoted to the topic, with contributions by Baumol, Cowen, Peacock and Throsby.

3 A good example is the "Opera Spectacular" which tours the whole world. Its production of Aida is normally performed in sports stadiums, and has so far attracted many millions of visitors. Open air performances have attendances of up to 45,000 people (in Montreal), which can be attributed to its concrete visual elements (e.g. a sphinx 15 meters high, live elephants and camels), a large number of performers (roughly 600 supernumeraries) as well as the extraordinary emphasis on acoustic quality. 
Festivals may even be compared to pilgrimages (Börsch-Supan 1993, p. 73) which also have an aura of mysticism, and are surrounded by much commercial activity.

4. Newsworthiness. Festivals are news, and attract the attention of television, radio and the print media, which is otherwise impossible to get to the same degree, and especially free of charge. It is easy to get media people to report on the opening of a festival. This media attention strengthens the festival director's position vis à vis politicians, sponsors and donors.

Operatic and musical performers get some media attention on opening nights but with few exceptions, i.e. short of a scandal, the respective reports are digested by only a small percentage of the population while the rest does not bother. Festivals offer much better opportunities to get media attention because they present themselves every year as a special occasion.

Closely connected to novelty is the limited duration of festivals. The restricted time raises prospective visitors' incentives to really attend, while a visit to the local opera house or concert hall is easily put off in the expectation that nothing is lost thereby.

5. Low cost to visitors. Festivals are closely connected to tourism (see e.g. Getz 1989, O'Hagan 1992, p. 65). The French characteristically like to name them "estivals", in order to indicate that they normally take place in the summer tourist season. It has been econometrically estimated that as tourists have their income situation improve back home, they increase their vacation expenditure and correspondingly demand more cultural experiences during their stay abroad (Gapinski 1988). A considerable share of visitors comes from out of town, from another region, and often from a foreign country.

The combination of a cultural event with tourism lowers the individuals' cost of attending in various respects. In the case of the increasingly popular package tours, the consumers only have to take the initial decision and all the rest is taken care of by the travel agent. In the case of operatic and other musical performances, where it is often burdensome to acquire the tickets, this reduction in decision and transaction costs is substantial. Festivals should thus be considered one input into a consumption production function (Becker 1976). The total cost of the output consumed is made up of the cost of the various inputs which comprise, among other expenditures, the travel costs which have been secularly declining (especially if one takes into account the reduced time input required). This 
argument, however, also holds to some extent for a combination of tourism with regular art venues.

6. Low price elasticity of demand. The strong attraction of festivals to tourists and people from out of town paying day-visits also affects the price elasticity of demand. Tourists tend to compare the ticket price to expenditures for the trip as a whole. A given price rise then appears small only and does not have much impact on demand (Thaler 1980).

The low price elasticity of demand, compared to the permanent venues, gives the managers of festivals more leeway to increase their revenue by increasing entrance fees. It may indeed be commonly observed that the entrance prices for festivals are often higher than for traditional performances. This suggests that entrance fees are more fully used as an income source when tourist demand is higher.

7. High demand by business. Festivals offer many opportunities to make money. Indeed, there is a large literature documenting the monetary profitability of such cultural events. Not only do they extend to the tourist industry but also to firms catering for the production of festivals. There is a direct benefit to the recording industry. CDs and videos of classical music have become a huge commercial enterprise, with correspondingly high profits.

Festivals provide an excellent opportunity to hire superstars for often very large crowds of spectators. This effect is greatly magnified if the performances are televised and propagated by CDs and videos. The recording companies also use festivals to launch the careers of their future stars. As festivals are less regulated than concert and opera houses, these companies can more easily influence the program to favor the artists they have under contract (this has been particularly noted at the Salzburg Festival, Frey 1986). The same applies to the sponsoring activity of companies producing goods unrelated to the arts. At festivals, they can appear more prominently and can therefore expect more publicity from a performance for a given sum of money.

\section{Supply}

There are five major determinants of supply of festivals which contrast with the conditions faced by the permanent venues and contribute to the festival boom. 
1. Low production cost. The absolute cost of many festivals is certainly high. But it is low compared to the sum of money they would require if all the resource inputs used were attributed to them. Important resources are taken from the permanent venues and only marginal (additional) costs are covered by the festival itself.

As most festivals are organized during the summer holidays, they can hire much of the artistic and technical staff at marginal cost, as these persons are otherwise not employed. They can also to a considerable extent draw on volunteers. In the United Kingdom, for instance, almost 40 percent of the over 500 arts festivals are run by unpaid staff (Rolfe 1992, p. 1), but that source of labor is also important in virtually all festivals (see e.g. Curtis 1990, p. 4; O'Hagan and Purdy 1993, p. 161). The locations at which the festivals play are often "public" (they belong to the state or the church) and can be rented at a nominal charge, and are frequently free (Rolfe 1992, p. 62; Galeotti 1992, p. 133). This makes sense, as many of these venues are otherwise unused, as for example the Roman theatres in which some festivals (Verona and Orange are well-known cases in point) take place.

2. More scope for artistic creativity. Permanent opera houses and orchestras are strongly bound by the clientele they have to cater for. They often find it impossible to interpret classical plays in a new form, and even more to perform modern and/or unknown plays, because they risk losing their regular customers. The holders of season tickets with mostly conservative taste are, moreover, strongly interested in what is presented and form a powerful lobby, which can exert considerable pressure on the managers and the subsidygiving politicians if they are dissatisfied with "their" opera house or orchestras. As a consequence, the directors have little possibility of fulfilling their artistic conceptions of originality.

In contrast, independently organized festivals provide a possibility of exhibiting artistic creativity. Festivals may well specialize in an audience honoring unorthodoxy, excellence and special tastes. While a permanent opera house or orchestra only performing contemporary plays and music comes under heavy pressure from their established clientele, and is quickly forced by the subsidizing politicians to conform to broader tastes, a festival exclusively devoted to such contemporary art may well prosper. 
3. Evading government and trade union regulations. Cultural institutions' freedom to act is restricted by two major institutions, the government and the trade unions ${ }^{4}$.

(a) Administrative restrictions. In continental Europe, establishments of classical music and operas, as well as of art museums, are to a large extent either directly part of the public administration, or at least have to follow the administrative rules of the public sector as they are heavily subsidized by it. In particular, they are subject to the "nonaffectation principle", according to which all expenditures are covered by the public budget, and in return all the revenue goes to the public treasury. All revenue thereby gained is "taxed" by the public treasury at one hundred percent as the subsidy is correspondingly reduced. Indeed, the effort to gain own revenues is taxed at more than one hundred percent in the long run, because the budgetary authorities become aware of the money-earning potential and correspondingly tend to reduce future subsidies. As a result, arts institutions (as well as all other governmental units) have no incentive to gain revenue by their own efforts, e.g. by ticket sales or income from auxiliary activities, such as recordings of operatic and musical performances.

Many festivals are organized as private enterprises, in which public bodies are at best one of several members. As a consequence, the directors of music festivals do not have to conform to administrative regulations, and in particular do not have to transfer surpluses to the public treasury, but can use them in a way they find sensible, above all to invest them in innovative features of their festival. The directors risk losing their degree of freedom to the extent they accept, and become dependent on, public subsidies, in which case the festival's possibility of engaging in artistic originality is reduced to the low level corresponding to established opera houses and orchestras.

(b) Employment restrictions. One of the most stringent public regulations imposed on art institutions pertains to government sector employment. The virtual impossibility of dismissing inefficient or downright destructive employees, promoting and paying employees according to performance, and adjusting working hours to needs, are major factors reducing creative endeavors, and turning art institutions into mere bureaucracies. Additional regulations have been pushed through by the trade unions, and are often fully supported by the government. Festivals make it possible to evade at

4 This argument especially applies to Europe. In the United States, where generally less regulations are imposed on cultural institutions (at least compared to other institutions), the incentive to evade regulations 
least some employment restrictions, especially as most of the respective employees are only part-time and temporary, not union members, and therefore not legally bound by trade union regulations.

4. More sponsoring. Politicians and public officials have a pronounced interest in festivals. They not only respond to the respective demands of the arts world and the local business community, but it gives them an excellent opportunity of appearing in the media as "patrons of the arts" (with tax payers' money).

Business is also more prepared to sponsor festivals than regular activities where legal provisions often hinder sponsoring. The most important reason is certainly not only the higher media attention of these events and their particular contribution, but also that an individual firm has more control over the funds contributed, and sees less of it wasted by an inefficient bureaucracy than in opera houses. Sponsors "want a well-defined, highquality event aimed at specific audience" (The Economist, 5 Aug. 1989). For the reasons given above, the corporate sponsors also feel that their contributions add to cultural output, and do not simply induce the government to provide less subsidies.

5. Career enhancement. As a result of increased internationalization, particularly with European unification, many of the top positions in opera houses and orchestras are open to foreign competition. The normal career pattern has thus changed from staying all one's life in one house, and reaching a senior position by internal promotion. In order to successfully compete in this changed setting, the directors have to make themselves internationally known. An excellent means is to actively participate in festival.

The discussion has shown that festivals have substantial possibilities to be artistically innovative and at the same time economically successful. A major reason is that festivals are less bound by restrictions than are the traditional venues. However, government interventions have a perennial tendency to undermine these advantages. In particular, the way of subsidizing festivals may easily distort the incentives to be artistically innovative. This tendency is strengthened by the fact that accepting government subsidies in general means that the recipient festivals have to conform to the many restrictions going with public activities. The next section demonstrates for the case of the Salzburg Festival that this danger 
is indeed real, and that the outcome may well be that festivals become as inflexible as the traditional venues.

\section{Problems of Government Intervention}

As the general discussion of festivals has indicated, the government support of art and culture is not without problems. The Salzburg Festival (an extensive discussion from the economic point of view is given in Frey 1986) is taken as a prominent example. A law has been promulgated forcing the state to carry whatever deficit arises. The total deficit is covered jointly by the Austrian government, the Salzburg province and the city of Salzburg. The budget restrictions on the Salzburg Festival fund (with four directors and a president) are therefore extremely weak. Effective restrictions on deficit coverage can only arise if the financing possibilities of all the bodies subsidizing the festival were no longer adequate, and the law was correspondingly amended. Of course, not even in that case is the money just handed out to the Festival. Formally, it is decided by the four bodies mentioned above. Yet these bodies are constrained by the law requiring them to cover the deficit. Also, as the deficit concerns all four of them, it has the nature of a "public good": a particular body has only muted incentives to try to reduce the deficit. The benefits of such activity accrue to all while the considerable costs in terms of conflicts engendered fall on the body trying to reduce the deficit. Finally, the individual members of these bodies, mainly politicians and bureaucrats, have no incentive to fight for a reduction in the subsidy. They personally benefit from good relationships with the Festival organizers as they receive free entrance tickets and are invited to the trendy social occasions.

As a consequence of these extremely favorable conditions for the festival fund, its directorate pursues a remarkable redistributive policy. The Austrian taxpayer is burdened with financing the subsidies, while the benefits are divided among the directorate, the employees, the artists and a selected group of visitors. The wide discretionary room of the directors is reflected in the typical rent-seeking activities of the festival:

1. Entrance tickets are sold at prices lying substantially below the equilibrium price, with the consequence that demand constantly exceeds supply. For example, in 1981/2, when the number of persons attending amounted to 175,000 , a total of 35,000 requests for tickets 
were rejected. In this way, the directorate can claim to be charging "socially appropriate" prices, which in turn is good for their prestige. But the resulting costs have to be borne by the anonymous taxpayer. The directorate is, moreover, able to hand out tickets, which are otherwise hard, or impossible, to obtain for interested demanders, in a discriminatory fashion. The main recipients of these tickets are festival administration workers, presspersons and individuals from whom political support to the festival may be expected. The emergence of a black market in tickets, moreover, provides a fair-sized group (including hotel employees) with an opportunity to make money by selling the tickets at a higher price than the official price.

2. The quasi-automatic coverage of deficits allows artists and administration workers to receive considerably higher wages than elsewhere, i.e. pure rents are paid. This is evident from Table 1, which gives a comparison of wages for administrative staff of the Salzburg Festival and the Bundestheater in Vienna. It should be noted that the wages have been made comparable by the Austrian Court of Accounts (Oesterreichischer Rechnungshof 1984, 1988) - except that the Salzburg Festival plays only for a fraction of the time the Bundestheater does. The rents are not only paid in the form of excessively high current monetary incomes, but also in the form of additional retirement pension entitlements and a number of fringe benefits (gifts, subsidized travel, etc.). 
Table 1: Wages of Administrative Staff of the Salzburg Festival and the Vienna Bundestheater (with functionally equivalent duties); 1981-82, in Austrian Schillings.

Administrative area

Salzburg

Bundestheater

Ticket sales

814,000

314,000

Buildings

821,000

467,000

Press Office

775,000

434,000

Technical section

797,000

679,000

Note: The Salzburg Festival lasts five weeks, while the Bundestheater plays for ten months. The wages indicated have not been adjusted accordingly.

Source: Oesterreichischer Rechnungshof 1984, section 1.31.1.

3. The organizers of the Festival have little incentive to keep down costs and to aim at an efficient management. As a result there is widespread and considerable inefficiency and waste. A drive for efficiency would create serious conflicts with the artists and other employees while the cost savings only result in a reduction of the size of the subsidy received. Such a reduction is of little or no benefit to the Festival directors. Rather, with respect to their prestige and careers they greatly benefit from hiring the best possible artists and mounting highly acclaimed performances irrespective of costs. As the Rechnungshof stated in its report (RH 1984, 1.15.3), the organizers choose the plays to be performed independent of the expected monetary net return, and sometimes even violating obvious cost considerations.

\section{Conclusions}

The purpose of the discussion was to show that festivals offer great artistic and economic opportunities, but that at the same time these opportunities are also easy to destroy. There are two policy conclusions to be drawn: 
1. The government subsidies must be given with great care. From the very beginning it has to be carefully checked whether a planned festival needs any monetary subsidies at all. Alternative ways of support may be not only economically more efficient but also be preferable from the artistic point of view. In particular, the government can support a festival by allowing performances in public spaces and public venues. As most of them are little or not used alternatively, they should be given at a nominal or zero charge.

In case a monetary subsidy is in order, the incentive of the organizers should not be destroyed. They must be motivated to produce as large total social benefits as possible while keeping total social costs as low as possible. Total social benefits of course do not solely consist in monetary revenues but in the aggregate willingness to pay for the festival. Also, the purpose cannot be to minimize monetary cost but negative external effects (e.g. in terms of noise and additional traffic induced) have also to be considered.

Under no circumstance should the public subsidies work against an effort by the festival organizers to produce as much commercial revenue as possible without reducing artistic quality. In particular, they should not be punished by a reduction in the subsidy when they are able to raise revenue. Rather, such a laudable effort should be rewarded by increasing the subsidy. Clearly, such a policy rule stands against the teachings of traditional public finance as well as against practice. Nevertheless, it is compatible with an approach which takes the organizers' incentives into account.

2. The government should interfere as little as possible in the organization of festivals. An effort should be made to prevent the many restrictions hampering traditional venues from applying to festivals. Thus the rules governing the working hours of the artistic, administrative and, above all, technical staff should be adjusted to the special occasion, and the same should apply to pay scales.

Provided these two policy conclusions are observed, festivals have a chance to stay innovative and to keep adding to the cultural life of a large, and often disregarded, part of the population.

\section{References}


Baumol, William J. (1993). Social Wants and the Dismal Science: The Curious Case of the Climbing Costs of Health and Teaching. Mimeo. C. V. Starr Center for Applied Economics, New York University.

Baumol, William J. and Hilda Baumol (1984). On Inflation in the Arts: A Summing up. In: Hilda Baumol and William J. Baumol (eds) Inflation and the Performing Arts. New York and London: New York University Press: 173-195.

Baumol, William J. and William G. Bowen (1966). Performing Arts - The Economic Dilemma. Cambridge, MA.: Twentieth Century Fund.

Becker, Gary S. (1976). The Economic Approach to Human Behavior. Chicago: Chicago University Press.

Blau, Judith R. (1989). Culture as Mass Culture. In: Arnold W. Foster and Judith R. Blau (eds.), Art and Society. Readings in the Sociology of the Arts. Albany, N.Y.: State University of New York: 141-176.

Börsch-Supan, Helmut (1993). Kunstmuseen in der Krise. Chancen, Gefährdungen, Aufgaben in mageren Jahren. Nördlingen: Deutscher Kunstverlag.

Brosio, Giorgio and Walter Santagata (1992). Rapporto sull économia delle arti e dello spectacolo in Italia. Torino: Fondazione Agnelli.

Curtis, Ruth (1990). Community and Small Scale Festivals. National Arts and Media Strategy Unit, Arts Council. London: 1-10.

DiMaggio, Paul and Michael Useem (1989). Cultural Democracy in a Period of Cultural Expansion: The Social Composition of Arts Audiences in the United States. In: Arnold W. Foster and Judith R. Blau (eds.), Art and Society. Readings in the Sociology of the Arts. Albany, N.Y.: State University of New York: 141-176.

Dümling, Albrecht (1992). Vorsicht Kommerz! Musikfestivals am Scheideweg. Neue Zeitschrift für Musikwissenschaft 7/8: 8-12.

Frey, Bruno S. (1986). The Salzburg Festival - from the Economic Point of View. Journal of Cultural Economics 10: 27-44. 
Frey, Bruno S. (1994). The Economics of Music Festivals. Journal of Cultural Economics 18: 29-39.

Frey, Bruno S. (1996). Has Baumol's Cost Disease disappeared in the perfoming arts? Ricerche Economiche 50: 173-182.

Frey, Bruno S. (1999). State Support and Creativity in the Arts: Some New Considerations. Journal of Cultural Economics 23 (1-2): 71-85.

Frey, Bruno S. (2000). Art and Economics. Heidelberg and New York: Springer Verlag.

Frey, Bruno S. and Isabelle Busenhart (1996). Special Exhibitions and Festivals; Culture's Booming Path to Glory. In: Victor A. Ginsburgh and Pièrre-Michel Menger (eds) Economics of the Arts. Selected Essays. Amsterdam: Elsevier: 275-302.

Frey, Bruno S. and Werner W. Pommerehne (1989). Muses and Markets: Explorations in the Economics of the Arts. Oxford: Blackwell.

Galeotti, Gianluigi (1992). Riflettori sull'iposcenio: elementi per un'analisi economica del Festival di Spoleto. In: Giorgio Brosio and Walter Santagata (eds.). Rapporto sull'economia delle arti e dello spettacolo in Italia. Torino: Fondazione Agnelli: 125-147.

Gapinski, James H. (1988). Tourism's Contribution to the Demand for London's Lively Arts. Applied Economics 20: 957-968.

Getz, Donald (1989). Special Events. Defining the Product. Tourism Management: 125-137.

Getz, Donald and Wendy Frisby (1988). Evaluating Management Effectiveness in Community-Run Festivals. Journal of Travel Research 27: 22-27.

L'Expansion (1994). En avant la musique. Special été, No 481: 32-35.

Maillard, Cécile (1994). A quoi servent les festivals? Grandes Lignes TGV 18: 65-66.

Mitchell, Claire J. A. and Geoffrey Wall (1989). The Arts and Employment: A Case Study of the Stratford Festival. Growth and Change 20 (4): 31-40.

O'Hagan, John W. (1992). The Wexford Opera Festival: A Case for Public Funding? In: Ruth Towse and Abdul Khakee (eds.). Cultural Economics. Berlin: Springer: 61-66. 
O'Hagan, John W. and Christopher T. Duffy (1987). The Performing Arts and the Public Purse: An Economic Analysis. Dublin: Irish Arts Council.

O'Hagan, John W. and Mark Purdy (1993). The Theory of Non-Profit Organisations: An Application to a Performing Arts Enterprise. Economic and Social Review 24: 155-167.

Österreichischer Rechnungshof (1984). Bericht über die Gebahrung des Bundes mit Mitteln der Kunst- und der Sportförderung. Vienna: Österreichische Staatsdruckerei.

Österreichischer Rechnungshof (1988). Nachtrag zum Tätigkeitsbereich des Rechunungshofes. Vienna: Österreichische Staatsdruckerei.

Pahlen, Kurt (1978). Erster Europäischer Festspielführer 1978. München: Goldmann.

Peacock, Alan T. (1984). Economics, Inflation and the Performing Arts. In: Baumol and Baumol (eds.) Inflation and the Performing Arts. New York and London: New York University Press: 71-85.

Pommerehne, Werner W. (1992). Opernfestspiele - ein Fall für öffentliche Subventionen? Homo Oeconomicus 9: 229-262.

Rolfe, Heather (1992). Arts Festivals in the U.K. London: Policy Studies Institute.

Thaler, Richard H. (1980). Toward a Positive Theory of Consumer Choice. Journal of Economic Behaviour and Organization 1: 39-60.

Throsby, David C. and Glenn A. Withers (1979). The Economics of the Performing Arts. London and Melbourne: Arnold.

Towse, Ruth (ed.) (1997). Baumol's Cost Disease. The Arts and other Victims. Edward Elgar: Cheltenham U.K. and Northampton, USA.

Vaughan, David Roger (1980). Does a Festival Pay? In: James L. Shanahan, William S. Hendon and Alice J. MacDonald (eds.), Economic Policy for the Arts. Cambridge, MA.: Abt: $319-331$. 